\title{
PENGUKURAN DAN EVALUASI KINERJA KARYAWAN PERUSAHAAN DENGAN METODE HUMAN RESOURCES SCORECARD (HRSC) DI PT. SHELTER NUSANTARA SURABAYA
}

\author{
Rr. Rochmoeljati \\ Jurusan Teknik Industri, Fakultas Teknologi Industri, \\ Universitas Pembangunan Nasional "Veteran" Jawa Timur
}

\begin{abstract}
ABSTRAKSI
Human Resources Scorecard adalah suatu sistem pengukuran sumber daya manusia yang mengkaitkan orang - strategi - kinerja untuk menghasilkan perusahaan yang unggul. Human Resource Scorecard menerjemahkan visi, misi dan strategi perusahaan ke dalam seperangkat ukuran yang menyeluruh yang memberi kerangka kerja bagi pengukuran dan sistem manajemen strategis.

PT. Shelter Nusantara merupakan suatu perusahaan penyedia jasa keamanan selama ini hanya memperhatikan bagaimana menjalankan proses operasional saja dan berjalan sesuai dengan prosedur yang berlaku tanpa memperhatikan apakah kinerja karyawan terdapat peningkatan atau tidak. Meskipun kondisi kinerja menunjukkan hasil yang cukup baik dan diharapkan masih dapat dioptimalkan. Namun selama ini perusahaan masih belum ada suatu system pengukuran kinerja sumber daya manusia yang baku dan komprehensif atau menyeluruh. Tiap KPI dan perspektif yang ada dalam metode Human Resources Scorecard dibobotkan dengan menggunakan metode Analytical Hierarchy Process (AHP) melalui perangkat lunak Expert Choice Versi 9.

Score pengukuran kinerja karyawan PT. Shelter Nusantara pada tahun 2007 sebesar 3.342 yang digolongkan kinerja karyawan, sedangkan skor untuk tiap perspektif adalah sebagai berikut untuk Perspective Financial sebesar 3.252, untuk Perspective Customer sebesar 2.686, untuk Perspective Internal Business Process sebesar 3.519, dan untuk Perspective Learning and Growth sebesar 4.4.
\end{abstract}

Kata Kunci : Human Resources Scorecard, Perspective Financial, Perspective Customer, Perspective Internal Business Process, Perspective Learning and Growth, Analytical Hierarchy Process.

\section{PENDAHULUAN}

Pengukuran kinerja karyawan sangat diperlukan oleh perusahaan, baik itu pengukuran secara sederhana maupun secara terorganisir menggunakan suatu metode pengukuran kinerja karyawan. Meskipun selama ini pengukuran kinerja karyawan hanya dianggap remeh perusahaan dan perusahaan hanya mengambil keputusan terhadap kinerja karyawan hanya berdasar pada hasil kerja mereka, akan tetapi dengan adanya pengukuran ini perusahaan akan mengetahui aspek aspek apa saja yang bisa mempengaruhi kinerja karyawan. Salah satu metode pengukuran kinerja yang ada adalah metode Human Resource Scorecard. Human Resource Scorecard menerjemahkan visi, misi dan strategi perusahaan ke dalam seperangkat ukuran yang menyeluruh yang memberi kerangka kerja bagi pengukuran dan sistem manajemen strategis.

PT. Shelter Nusantara merupakan suatu perusahaan penyedia jasa keamanan yang berdiri pada tahun 2002. Semenjak PT. Shelter Nusantara 
didirikan, perusahaan hanya memperhatikan bagaimana menjalankan proses operasional saja dan berjalan sesuai dengan prosedur yang berlaku tanpa memperhatikan apakah kinerja karyawan terdapat peningkatan atau tidak. Pimpinan perusahaan menganggap karyawan tersebut telah bekerja dengan baik apabila telah mengerjakan tugasnya dengan baik tanpa adanya kesalahan dan sesuai dengan prosedur yang berlaku pada perusahaan. Namun selama ini perusahaan masih belum ada suatu system pengukuran kinerja sumber daya manusia yang baku dan komprehensif atau menyeluruh.

Permasalahan yang dihadapi oleh PT. Shelter Nusantara adalah banyaknya karyawan yang melanggar kontrak kerja dan semakin banyaknya karyawan yang mendapat surat peringatan. Hal ini akan mempengaruhi keberhasilan suatu perusahaan agar mampu bersaing dengan perusahaan lainnya. Karyawan merupakan sumber daya manusia yang sangat berharga bagi suatu perusahaan dan menjadi kunci sukses keberhasilan perusahaan. Oleh karena itu, sumber daya manusia dalam perusahaan harus dikelola dengan baik sehingga perusahaan dapat berjalan dengan baik.

Tujuan yang ingin dicapai dalam penelitian ini adalah sebagai berikut untuk mengetahui tingkat kinerja karyawan tahun 2007 di PT. Shelter Nusantara., dan memberikan masukan berupa respon teknis terhadap indikator - indikator yang belum mencapai target perusahaan.

\section{TINJAUAN PUSTAKA}

\section{Definisi Performance Measurement (Pengukuran Kinerja)}

Pengukuran kinerja merupakan proses untuk mengukur dan menilai bagaimana kontribusi sumber daya manusia terhadap kinerja organisasi. Menurut Patrick L. Romano (1989), “ Pengukuran kinerja (performansi) merupakan salah satu proses dalam sistem pengendali manajemen dengan membandingkan dan mengevaluasi antara rencana yang dibuat dan hasil yang dicapai, menganalisa penyimpangan yang terjadi dan melakukan perbaikan. “

Human Resources Scorecard (HRSC)

Sejak diperkenalkan oleh Kaplan dan Norton tahun 1992, konsep "Balanced Scorecard" telah diimplementasikan di sekitar 200 perusahaan di Amerika. Di dalam perkembangannya karena suatu organisasi sangat didominasi oleh "human capital" dan modal "intangible" lainnya, oleh sebab itu kemudian berkembang metode "Human Resources Scorecard” yang menawarkan langkah langkah penting guna mengelola strategi sumber daya manusia. (Jurnal Human Resource Scorecard)

Human Resources Scorecard merupakan Balanced Scorecard dengan pendekatan Human Resources Department dimana sistem pengukuran kinerja terintegrasi menggambarkan sistem sumber daya manusia dan Key Performance Indicators yang dihasilkan berdasarkan pada manajemen sumber daya manusia.

Bagaimana Human Resources Scorecard ini dihasilkan adalah 1). Menentukan proses bisnis dari masing - masing perspektif, 2). Menentukan Key Performance Indicators dari proses bisnis perspektif, 3) . Melakukan pengukuran kinerja aktual versus target dari masing - masing Key Performance Indicator, 4). 
Normalisasi ukuran yang bermacam - macam menjadi score range, 5). Menentukan pencapaian sistem sumber daya manusia keseluruhan.

Dalam Human Resources Scorecard, masing - masing perspektif dapat dijelaskan sebagai berikut :

- Perspektif Financial

Adalah tolok ukur financial untuk memberi ringkasan dari konsekuensi ekonomis akibat dari kebijakan - kebijakan yang telah diambil, dalam hal ini adalah berkenaan dengan perspektif customer, internal dan learning and growth. Berkaitan dengan profitabilitas, dan lain - lain.

- Perspektif Customer

Adalah tolok ukur karyawan sebagai aset, sebagai pengguna atau output dari implementasi strategi sumber daya manusia atau lebih tepatnya merupakan dampak terhadap customer dari perspektif internal dan perspektif learning and growth.

Ukuran dari perspektif ini misalnya Employee Satisfaction, yaitu ukuran ukuran yang menunjukkan tingkat kepuasan karyawan dalam hal pemenuhan kriteria yang ditetapkan.

- Perspektif Internal Business Process

Memfokuskan pada proses internal yang akan memberikan dampak pada kepuasan customer dan mencapai tujuan financial dari organisasi. Perspektif ini meliputi inovasi, proses dan pelayanan.

- Perspektif Learning and Growth

Memfokuskan pada sistem dan strategi untuk pengembangan sumber daya manusia, misalnya melalui pelatihan.

Keuntungan implementasi Human Resources Scorecard (GML Performance consulting, 2001) adalah 1). Menggambarkan peran dan konstribusi sumber daya manusia kepada pencapaian visi perusahaan secara jelas dan terukur. 2). Memampukan profesional sumber daya manusia dalam mengendalikan biaya yang dikeluarkan dan nilai yang dikonstribusikan. 3). Memberikan gambaran hubungan sebab dan akibat. 4) Memampukan profesional sumber daya manusia mengelola tanggung jawabnya yang strategis. 5). Fleksibel.

\section{Analitycal Hierarchy Process (AHP)}

AHP yang dikembangkan oleh Thomas L. Saaty, dapat memecahkan masalah kompleks yang berkriteria banyak. Secara umum langkah-langkah yang harus dilakukan dalam menggunakan AHP adalah sebagai berikut (Suryadi dan Ramdhani, 1998):

1. Mendefinisikan permasalahan dan menentukan secara spesifik tujuan dan solusi yang diinginkan.

2. Menyusun masalah ke dalam struktur hirarki sehingga permasalahan yang kompleks dapat ditinjau dari sisi detail dan terukur.

3. Menyusun matriks-matriks perbandingan berpasangan untuk setiap level di bawahnya, sebuah matriks untuk setiap elemen yang tepat berada pada level di atasnya. 
4. Pengisian matriks perbandingan berpasangan oleh pengambil keputusan. Dibutuhkan sebanyak n(n-1)/2 judgement untuk setiap matriks pada tahap 3 di atas.

5. Melakukan pengujian konsistensi dengan menggunakan eigen value terhadap perbandingan berpasangan antar elemen yang didapatkan pada tiap level hirarki.

6. Langkah 3,4 dan 5 diulang setiap level cluster dan hirarki.

7. Melakukan sintesis untuk menyusun bobot vektor eigen tiap elemen masalah pada setiap level hirarki.

8. Mengevaluasi konsistensi hirarki, jika nilainya lebih besar 0.1 maka terjadi inkonsistensi, kualitas data harus diperbaiki.

\section{Perhitungan Bobot Elemen}

Secara sederhana, langkah - langkah untuk menentukan bobot pada setiap kriteria dalam penentuan alternatif keputusan adalah sebagai berikut :

- Menentukan geometric mean, dengan formulasi:

$\mathrm{MG}=\sqrt[n]{\sum_{i=1}^{n} X i}$

Dimana : $\mathrm{MG}=$ geometric mean

$$
\begin{array}{ll}
\mathrm{Xi} & =\text { alternatif } \mathrm{ke}-\mathrm{i} \\
\mathrm{n} & =\text { jumlah data }
\end{array}
$$

- Melakukan proses Normalisasi dengan membuat proporsi geometric mean dengan formulasi:

$$
\begin{aligned}
\mathrm{Pi}=\frac{M G i}{\sum_{i=1}^{n} M G i} & \\
\text { Dimana }: \mathrm{Pi} & =\text { proporsi alternatif } \mathrm{ke}-\mathrm{i} \\
\mathrm{Mgi} & =\text { geometric mean data } \mathrm{ke}-\mathrm{i} \\
\mathrm{n} \quad & =\text { jumlah data }
\end{aligned}
$$

- Menentukan bobot nilai tiap alternatif terhadap kriteria, dengan formulasi:

$$
\begin{aligned}
\mathrm{Vi}=\sum_{i=1}^{n} \operatorname{Pix} W i & \\
\text { Dimana }: \mathrm{Pi} & =\text { proporsi alternatif } \mathrm{ke}-\mathrm{i} \\
\mathrm{Vi} & =\text { bobot nilai alternatif } \mathrm{ke}-\mathrm{i} \\
\mathrm{Wi} & =\text { bobot kriteria } \mathrm{ke}-\mathrm{i}
\end{aligned}
$$

\section{Pengukuran Konsistensi Setiap Matriks Perbandingan}

Pengukuran konsistensi dari suatu matriks itu sendiri didasarkan atas suatu eigen value maksimum. Rumus dari indeks konsistensi (CI) adalah

$$
C I=\frac{\left(\lambda_{\text {maks }}-n\right)}{(n-1)}
$$

Dimana : $\lambda_{\max }=$ eigen value maksimum

$$
\mathrm{n}=\text { ukuran matriks }
$$


Berikut ini indeks random untuk matriks berukuran 3 sampai 10 (matriks berukuran 1 dan 2 mempunyai inkonsistensi 0)

Tabel 1 Nilai Indeks Random (RI)

\begin{tabular}{|c|c|c|c|c|c|c|c|c|}
\hline 1,2 & 3 & 4 & 5 & 6 & 7 & 8 & 9 & 10 \\
\hline 0,00 & 0,58 & 0,90 & 1,12 & 1,24 & 1,32 & 1,41 & 1,45 & 1,49 \\
\hline
\end{tabular}

(Sumber : Analitical Hierarchy Process, Bambang Brodjonegoro, 1991)

Rumus dari konsistensi / inkonsistensi (CR) itu sendiri dapat dituliskan sebagai berikut :

$$
\begin{array}{ll}
\mathrm{CR}=\mathrm{CI} / \mathrm{RI}, \quad \text { dimana }: & \mathrm{CR}=\text { Consistensi Ratio } \\
& \mathrm{CI}=\text { Indeks Konsistensi } \\
& \mathrm{RI}=\text { Indeks Random }
\end{array}
$$

Tingkat inkonsistensi yang masih bisa diterima adalah tingkat inkonsistensi sebesar $10 \%$ kebawah (Bambang PS Brodjonegoro, 1991 : 15)

\section{METODE PENELITIAN}

Dalam penelitian ini variabel-variabel yang digunakan terbagi menjadi dua yaitu :

1. Variabel Terikat

Variabel terikat merupakan variabel yang dipengaruhi atau disebabkan oleh variabel bebas. Dalam penelitian ini yang menjadi variabel terikat adalah kinerja karyawan.

2. Variabel Bebas

Variabel bebas merupakan variabel yang mempengaruhi atau menyebabkan variabel terikat. Variabel bebas yang digunakan dalam penelitian ini ada empat perspektif, antara lain :

1. Perspective Financial, meliputi : Prosentase biaya pelatihan / Training Cost (TC), Prosentase biaya pengadaan tenaga kerja / Employee Procurement Cost (EPC) dan Biaya Produktivitas karyawan / Employee Productivity Cost (EPDC).

2. Perspective Customer, meliputi : Prosentase tingkat absensi, Prosentase karyawan yang mendapat Surat Peringatan, Prosentase karyawan yang melanggar kontrak kerja, Tingkat kepuasan karyawan / Employee Satisfaction Index (ESI) dan Waktu rata - rata karyawan menganggur karena rolling.

3. Perspective Internal Business Process, meliputi : Prosentase tertangkapnya kasus pencurian, Prosentase peningkatan permintaan personel dan Prosentase frekuensi Internal Meeting.

4. Perspective Learning and Growth, meliputi : Prosentase karyawan yang lulus Basic Training, Prosentase jumlah Regular Training dan Jumlah jam pelatihan yang diadakan oleh perusahaan bagi karyawannya. 


\section{HASIL DAN PEMBAHASAN}

Tabel 2 Perancangan Pengukuran Perspective Financial

\begin{tabular}{|c|c|c|c|c|c|}
\hline No & Tujuan & KPI & Target & Penilaian & Skor \\
\hline \multirow{2}{*}{1} & \multirow{2}{*}{$\begin{array}{l}\text { Meningkatkan efisiensi } \\
\text { di bidang Sumber Daya } \\
\text { Manusia }\end{array}$} & $\begin{array}{l}\text { Prosentase } \\
\text { Training Cost } \\
(T C)\end{array}$ & $\begin{array}{c}\text { TC } \\
\text { mencapai } \\
80 \%\end{array}$ & $\begin{array}{c}\mathrm{TC} \geq 90 \% \\
85 \% \leq \mathrm{TC}<90 \% \\
80 \% \leq \mathrm{TC}<85 \% \\
75 \% \leq \mathrm{TC}<80 \% \\
\mathrm{TC}<75 \%\end{array}$ & $\begin{array}{l}5 \\
4 \\
3 \\
2 \\
1\end{array}$ \\
\hline & & $\begin{array}{l}\text { Prosentase } \\
\text { Employee } \\
\text { Procurement } \\
\text { Cost }(\text { EPC })\end{array}$ & $\begin{array}{c}\text { EPC } \\
\text { mencapai } \\
80 \%\end{array}$ & $\begin{array}{c}\mathrm{EPC} \geq 90 \% \\
85 \% \leq \mathrm{EPC}<90 \% \\
80 \% \leq \mathrm{EPC}<85 \% \\
75 \% \leq \mathrm{EPC}<80 \% \\
\mathrm{EPC}<75 \%\end{array}$ & $\begin{array}{l}5 \\
4 \\
3 \\
2 \\
1\end{array}$ \\
\hline 2 & $\begin{array}{l}\text { Meningkatkan } \\
\text { produktivitas karyawan }\end{array}$ & $\begin{array}{l}\text { Employee } \\
\text { Productivity Cost } \\
\text { (EPDC) }\end{array}$ & $\begin{array}{c}\text { EPDC } \\
\text { mencapai } \\
\text { Rp. } 3.7 \mathrm{jt}\end{array}$ & $\begin{array}{c}E P D C \geq 4.5 \mathrm{jt} \\
4 \mathrm{jt} \leq \mathrm{EPDC}<4.5 \mathrm{jt} \\
3.5 \mathrm{jt} \leq \mathrm{EPDC}<4 \mathrm{jt} \\
3 \mathrm{jt} \leq \mathrm{EPDC}<3.5 \mathrm{jt} \\
\mathrm{EPDC}<3 \mathrm{jt}\end{array}$ & $\begin{array}{l}5 \\
4 \\
3 \\
2 \\
1\end{array}$ \\
\hline
\end{tabular}

( Sumber : Data Internal Perusahaan )

Keterangan :

TC

: Training Cost

EPC : Biaya Pengadaan Tenaga Kerja

EPDC : Biaya Produktivitas Karyawan

\section{Perspective Customer}

Tabel 3 Perancangan Pengukuran Perspective Customer

\begin{tabular}{|c|c|c|c|c|c|}
\hline No & Tujuan & KPI & Target & Penilaian & Skor \\
\hline \multirow[b]{2}{*}{1} & \multirow{2}{*}{$\begin{array}{l}\text { Meningkatkan } \\
\text { kedisiplinan } \\
\text { karyawan }\end{array}$} & $\begin{array}{l}\text { Prosentase } \\
\text { tingkat } \\
\text { absensi }\end{array}$ & $\begin{array}{l}\text { ABS } \\
\text { kurang } \\
\text { dari } 1 \%\end{array}$ & $\begin{array}{c}\mathrm{ABS}=0 \% \\
0 \%>\mathrm{ABS} \geq 1 \% \\
1 \%>\mathrm{ABS} \geq 2 \% \\
2 \%>\mathrm{ABS} \geq 3 \% \\
\mathrm{ABS}>3 \%\end{array}$ & $\begin{array}{l}5 \\
4 \\
3 \\
2 \\
1\end{array}$ \\
\hline & & $\begin{array}{l}\text { Prosentase } \\
\text { jumlah } \\
\text { karyawan } \\
\text { yang } \\
\text { mendapat } \\
\text { SP } \\
\end{array}$ & $\begin{array}{l}\text { KSP } \\
\text { kurang } \\
\text { dari } 3 \%\end{array}$ & $\begin{array}{c}\mathrm{KSP}<3 \% \\
3 \% \leq \mathrm{KSP}<7 \% \\
7 \% \leq \mathrm{KSP}<11 \% \\
11 \% \leq \mathrm{KSP}<15 \% \\
\mathrm{KSP}>15 \%\end{array}$ & $\begin{array}{l}5 \\
4 \\
3 \\
2 \\
1\end{array}$ \\
\hline 2 & $\begin{array}{l}\text { Meningkatkan } \\
\text { loyalitas } \\
\text { karyawan dalam } \\
\text { bekerja }\end{array}$ & $\begin{array}{l}\text { Prosentase } \\
\text { karyawan } \\
\text { yang } \\
\text { melanggar } \\
\text { kontrak }\end{array}$ & $\begin{array}{l}\text { KMKK } \\
\text { kurang } \\
\text { dari } 1 \%\end{array}$ & $\begin{array}{c}\mathrm{KMKK}=0 \% \\
0 \%>\mathrm{KMKK} \geq 1 \% \\
1 \%>\mathrm{KMKK} \geq 2 \% \\
2 \%>\mathrm{KMKK} \geq 3 \% \\
\mathrm{KMKK}>3 \%\end{array}$ & $\begin{array}{l}5 \\
4 \\
3 \\
2 \\
1\end{array}$ \\
\hline 3 & $\begin{array}{l}\text { Meningkatkan } \\
\text { kepuasan } \\
\text { karyawan } \\
\text { dalam bekerja. }\end{array}$ & $\begin{array}{l}\text { Employee } \\
\text { Satisfaction } \\
\text { Index (ESI) }\end{array}$ & $\begin{array}{l}\text { ESI } \\
\text { mencapai } \\
1800 \text { point }\end{array}$ & $\begin{array}{c}\mathrm{ESI} \geq 2227 \\
1803 \leq \mathrm{ESI}<2227 \\
1379 \leq \mathrm{ESI}<1803 \\
955 \leq \mathrm{ESI}<1379 \\
\mathrm{ESI}<955\end{array}$ & $\begin{array}{l}5 \\
4 \\
3 \\
2 \\
1\end{array}$ \\
\hline
\end{tabular}




\begin{tabular}{|c|c|c|c|c|c|}
\hline 4 & $\begin{array}{l}\text { Menurunkan } \\
\text { waktu rata - } \\
\text { rata karyawan } \\
\text { menganggur }\end{array}$ & $\begin{array}{l}\text { Waktu rata } \\
-\quad \text { rata } \\
\text { karyawan } \\
\text { menganggur } \\
\text { karena } \\
\text { rolling }\end{array}$ & $\begin{array}{l}\text { RKM } \\
\text { kurang } \\
\text { dari } 6 \text { hari }\end{array}$ & $\begin{array}{c}\mathrm{RKM}<3 \text { hari } \\
3 \text { hari } \leq \mathrm{RKM}<13 \text { hari } \\
13 \text { hari } \leq \mathrm{RKM}<23 \\
\text { hari } \\
23 \text { hari } \leq \mathrm{RKM}<33 \\
\text { hari } \\
\mathrm{RKM}>33 \text { hari }\end{array}$ & $\begin{array}{l}5 \\
4 \\
3 \\
2 \\
1\end{array}$ \\
\hline
\end{tabular}

( Sumber : Data Internal Perusahaan)

Keterangan :

ABS

: Abseinteism

KSP : Karyawan yang mendapat SP ( Surat Peringatan )

KMKK : Karyawan yang melanggar kontrak kerja

ESI : Employee Satisfaction Index (Indeks Kepuasan Karyawan)

RKM : Waktu rata - rata karyawan menganggur karena rolling

Perspective Internal Business Process

Tabel 4 Perancangan Pengukuran Perspective Internal Business Process

\begin{tabular}{|c|c|c|c|c|c|}
\hline \multirow{2}{*}{ No } & \multirow{2}{*}{ Tujuan } & \multirow{2}{*}{\multicolumn{2}{|c|}{\begin{tabular}{l|l} 
KPI & Target
\end{tabular}}} & \\
\hline & & & & Penilaian & Skor \\
\hline \multirow[t]{2}{*}{1.} & \multirow[t]{2}{*}{$\begin{array}{l}\text { Peningkatan } \\
\text { karyawan yang } \\
\text { berkualitas }\end{array}$} & $\begin{array}{l}\text { Prosentase } \\
\text { tertangkapnya } \\
\text { kasus } \\
\text { pencurian }\end{array}$ & $\begin{array}{l}\text { TKP } \\
\text { mencapai } \\
80 \%\end{array}$ & $\begin{array}{c}\text { TKP } \geq 90 \% \\
80 \% \leq \mathrm{TKP}<90 \% \\
70 \% \leq \mathrm{TKP}<80 \% \\
60 \% \leq \mathrm{TKP}<70 \% \\
\text { TKP }<60 \%\end{array}$ & $\begin{array}{l}5 \\
4 \\
3 \\
2 \\
1\end{array}$ \\
\hline & & $\begin{array}{l}\text { Peningkatan } \\
\text { permintaan } \\
\text { personel }\end{array}$ & $\begin{array}{l}\text { PPP } \\
\text { Mencapai } \\
20 \%\end{array}$ & $\begin{array}{c}\mathrm{PPP} \geq 30 \% \\
25 \% \leq \mathrm{PPP}<30 \% \\
20 \% \leq \mathrm{PPP}<25 \% \\
15 \% \leq \mathrm{PPP}<20 \% \\
\mathrm{PPP}<15 \%\end{array}$ & $\begin{array}{l}5 \\
4 \\
3 \\
2 \\
1 \\
\end{array}$ \\
\hline 2. & $\begin{array}{l}\text { Peningkatan } \\
\text { Quality } \\
\text { Relationship }\end{array}$ & $\begin{array}{l}\text { Prosentase } \\
\text { frekuensi } \\
\text { internal } \\
\text { meeting }\end{array}$ & $\begin{array}{l}\text { FIM } \\
\text { mencapai } \\
20 \%\end{array}$ & $\begin{array}{c}\text { FIM } \geq 25 \% \\
20 \% \leq \text { FIM }<25 \% \\
15 \% \leq \text { FIM }<20 \% \\
10 \% \leq \text { FIM }<15 \% \\
\text { FIM }<10 \%\end{array}$ & $\begin{array}{l}5 \\
4 \\
3 \\
2 \\
1\end{array}$ \\
\hline
\end{tabular}

( Sumber : Data Internal Perusahaan)

Keterangan :

TKP : Tertangkapnya kasus pencurian

PPP : Peningkatan permintaan personel

FIM : Frekuensi Internal Meeting 


\section{Perspective Learning and Growth}

Tabel 5 Perancangan Pengukuran Perspective Learning and Growth

\begin{tabular}{|c|c|c|c|c|c|}
\hline No & Tujuan & KPI & Target & Penilaian & Skor \\
\hline \multirow[t]{3}{*}{1.} & \multirow[t]{3}{*}{$\begin{array}{l}\text { Memberikan } \\
\text { pelatihan kepada } \\
\text { karyawan }\end{array}$} & $\begin{array}{l}\text { Prosentase } \\
\text { karyawan yang } \\
\text { lulus Basic } \\
\text { Training }\end{array}$ & $\begin{array}{l}\text { BT } \\
\text { menca } \\
\text { pai } 90 \\
\%\end{array}$ & $\begin{array}{c}\mathrm{KBT} \geq 90 \% \\
85 \% \leq \mathrm{KBT}<90 \% \\
80 \% \leq \mathrm{KBT}<85 \% \\
75 \% \leq \mathrm{KBT}<80 \% \\
\mathrm{KBT}<75 \%\end{array}$ & $\begin{array}{l}5 \\
4 \\
3 \\
2 \\
1\end{array}$ \\
\hline & & $\begin{array}{l}\text { Prosentase } \\
\text { jumlah Regular } \\
\text { Training }\end{array}$ & $\begin{array}{l}\text { RT } \\
\text { menca } \\
\text { pai } 9 \%\end{array}$ & $\begin{array}{c}\mathrm{RT} \geq 10 \% \\
7.5 \% \leq \mathrm{RT}<10 \% \\
5 \% \leq \mathrm{RT}<7.5 \% \\
2.5 \% \leq \mathrm{RT}<5 \% \\
\mathrm{RT} \leq 2.5 \%\end{array}$ & $\begin{array}{l}5 \\
4 \\
3 \\
2 \\
1\end{array}$ \\
\hline & & $\begin{array}{l}\text { Jumlah jam } \\
\text { pelatihan yang } \\
\text { diadakan oleh } \\
\text { perusahaan } \\
\text { bagi } \\
\text { karyawannya }\end{array}$ & $\begin{array}{l}\text { JJP } \\
\text { Menca } \\
\text { pai } \\
5030\end{array}$ & $\begin{array}{c}\text { JJP } \geq 5470 \\
5470 \leq \text { JJP }<4970 \\
4970 \leq \text { JJP }<4470 \\
4470 \leq \text { JJP }<3970 \\
\text { JJP } \leq 3970\end{array}$ & $\begin{array}{l}5 \\
4 \\
3 \\
2 \\
1\end{array}$ \\
\hline
\end{tabular}

( Sumber : Data Internal Perusahaan)

Keterangan :

BT : Basic Training

RT : Regular Training

JJP : Jumlah jam pelatihan

Tabel 6 Rekapitulasi Pengukuran Key Performance Indicator Tiap Perspektif Human

Resources Scorecard

\begin{tabular}{|c|c|c|c|c|}
\hline Perspective & Strategy Objectives & $\begin{array}{c}\text { Key Performance } \\
\text { Indicator }\end{array}$ & 2007 & $\begin{array}{c}\text { Tercapainya } \\
\text { Target }\end{array}$ \\
\hline \multirow[t]{3}{*}{ Financial } & \multirow{2}{*}{$\begin{array}{l}\text { Meningkatkan } \\
\text { efisiensi di bidang } \\
\text { Sumber Daya } \\
\text { Manusia }\end{array}$} & $\begin{array}{l}\text { Prosentase Training } \\
\text { Cost }(T C)\end{array}$ & $88.33 \%$ & Sudah \\
\hline & & $\begin{array}{l}\text { Prosentase Employee } \\
\text { Procurement Cost } \\
(\text { EPC) }\end{array}$ & $90 \%$ & Sudah \\
\hline & $\begin{array}{l}\text { Meningkatkan } \\
\text { produktivitas } \\
\text { karyawan }\end{array}$ & $\begin{array}{l}\text { Employee } \\
\text { Productivity Cost } \\
\text { (EPDC) }\end{array}$ & $\begin{array}{c}\text { Rp. } \\
3905064.249\end{array}$ & Sudah \\
\hline \multirow[t]{5}{*}{ Customer } & \multirow{2}{*}{$\begin{array}{l}\text { Meningkatkan } \\
\text { kedisiplinan } \\
\text { karyawan }\end{array}$} & $\begin{array}{l}\text { Prosentase tingkat } \\
\text { absensi }\end{array}$ & $0.04 \%$ & Sudah \\
\hline & & $\begin{array}{l}\text { Prosentase karyawan } \\
\text { yang mendapat SP }\end{array}$ & $11.22 \%$ & Belum \\
\hline & $\begin{array}{l}\text { Meningkatkan } \\
\text { loyalitas karyawan } \\
\text { dalam bekerja }\end{array}$ & $\begin{array}{l}\text { Prosentase karyawan } \\
\text { yang melanggar } \\
\text { kontrak kerja }\end{array}$ & $4.81 \%$ & Belum \\
\hline & $\begin{array}{l}\text { Meningkatkan } \\
\text { kepuasan karyawan }\end{array}$ & $\begin{array}{l}\text { Employee } \\
\text { Satisfaction Index } \\
\text { (ESI) }\end{array}$ & 1791 point & Belum \\
\hline & Menurunkan waktu & Waktu Rata - rata & 15 hari & Belum \\
\hline
\end{tabular}




\begin{tabular}{|l|l|l|c|c|}
\hline & $\begin{array}{l}\text { rata - rata karyawan } \\
\text { menganggur }\end{array}$ & $\begin{array}{l}\text { karyawan } \\
\text { menganggur karena } \\
\text { rolling }\end{array}$ & & \\
\hline $\begin{array}{l}\text { Internal } \\
\text { Business } \\
\text { Process }\end{array}$ & $\begin{array}{l}\text { Peningkatan } \\
\text { karyawan yang } \\
\text { berkualitas }\end{array}$ & $\begin{array}{l}\text { Prosentase } \\
\text { tertangkapnya kasus } \\
\text { pencurian }\end{array}$ & $84.91 \%$ & Sudah \\
\cline { 3 - 5 } & $\begin{array}{l}\text { Prosentase } \\
\text { peningkatan } \\
\text { permintaan personel }\end{array}$ & $23.45 \%$ & Sudah \\
\cline { 2 - 5 } & $\begin{array}{l}\text { Peningkatan Quality } \\
\text { Relationship }\end{array}$ & $\begin{array}{l}\text { Prosentase frekuensi } \\
\text { internal meeting }\end{array}$ & $21.48 \%$ & Sudah \\
\hline $\begin{array}{l}\text { Learning \& } \\
\text { Growth }\end{array}$ & $\begin{array}{l}\text { Memberikan } \\
\text { pelatihan kepada } \\
\text { karyawan }\end{array}$ & $\begin{array}{l}\text { Prosentase karyawan } \\
\text { lulus Basic Training }\end{array}$ & $91.98 \%$ & Sudah \\
\cline { 3 - 5 } & $\begin{array}{l}\text { Prosentase jumlah } \\
\text { RegularTraining }\end{array}$ & $9.62 \%$ & Sudah \\
\cline { 2 - 5 } & $\begin{array}{l}\text { Jumlah jam pelatihan } \\
\text { bagi karyawan }\end{array}$ & 4692 & Belum \\
\hline
\end{tabular}

( Sumber : Hasil Pengolahan data )

Tabel 7 Hasil Perhitungan dan Respon Teknis Sebagai Usulan Perbaikan

\begin{tabular}{|c|c|c|c|}
\hline Perspective & $\begin{array}{l}\text { Key Performance } \\
\text { Indicator }\end{array}$ & $\begin{array}{l}\text { Score } \\
\text { Terbobot }\end{array}$ & Usulan Perbaikan (Respon Teknis) \\
\hline \multirow[t]{3}{*}{ Financial } & $\begin{array}{l}\text { Prosentase biaya } \\
\text { pelatihan / Training } \\
\text { Cost (TC) }\end{array}$ & 1.248 & $\begin{array}{l}\text { Pada KPI ini hasil yang didapat sudah mencapai target } \\
\text { perusahaan, sehingga tidak diperlukan perbaikan. Tetapi } \\
\text { untuk menghasilkan kinerja yang baik sesuai dengan } \\
\text { tujuan perusahaan, maka KPI ini harus dipertahankan } \\
\text { atau lebih ditingkatkan lagi. }\end{array}$ \\
\hline & $\begin{array}{l}\text { - Prosentase biaya } \\
\text { pengadaan tenaga kerja } \\
\text { / Employee } \\
\text { Procurement Cost } \\
\text { (EPC) }\end{array}$ & 0.63 & $\begin{array}{l}\text { Pada KPI ini hasil yang didapat sudah mencapai target } \\
\text { perusahaan, sehingga tidak diperlukan perbaikan. Tetapi } \\
\text { untuk menghasilkan kinerja yang baik sesuai dengan } \\
\text { tujuan perusahaan, maka KPI ini harus dipertahankan } \\
\text { atau lebih ditingkatkan lagi. }\end{array}$ \\
\hline & $\begin{array}{l}\text { - Productivitas } \\
\text { karyawan / Employee } \\
\text { Productivity Cost } \\
\text { (EPDC) }\end{array}$ & 1.374 & $\begin{array}{l}\text { Pada KPI ini hasil yang didapat sudah mencapai target } \\
\text { perusahaan, sehingga tidak diperlukan perbaikan. Tetapi } \\
\text { untuk menghasilkan kinerja yang baik sesuai dengan } \\
\text { tujuan perusahaan, maka KPI ini harus dipertahankan } \\
\text { atau lebih ditingkatkan lagi. }\end{array}$ \\
\hline \multirow[t]{2}{*}{ Customer } & $\begin{array}{c}\text { - Prosentase tingkat } \\
\text { absensi }\end{array}$ & 0.68 & $\begin{array}{l}\text { Pada KPI ini hasil yang didapat sudah mencapai target } \\
\text { perusahaan, sehingga tidak diperlukan perbaikan. Tetapi } \\
\text { untuk menghasilkan kinerja yang baik sesuai dengan } \\
\text { tujuan perusahaan, maka KPI ini harus dipertahankan } \\
\text { atau lebih ditingkatkan. }\end{array}$ \\
\hline & $\begin{array}{l}\text { Prosentase jumlah } \\
\text { karyawan yang } \\
\text { mendapat SP }\end{array}$ & 0.278 & $\begin{array}{l}\text { Jumlah karyawan yang mendapat Surat Peringatan dapat } \\
\text { diminimalisasi apabila pihak manajemen dapat } \\
\text { memberikan sanksi tegas dan konsekuensi sesuai dengan } \\
\text { jenis pelanggaran dan berapa kali pelanggaran yang } \\
\text { dilakukan oleh karyawan. }\end{array}$ \\
\hline
\end{tabular}


Tabel 8 Hasil Perhitungan dan Respon Teknis Sebagai Usulan Perbaikan (Lanjutan)

\begin{tabular}{|c|c|c|c|}
\hline Perspective & $\begin{array}{l}\text { Key Performance } \\
\text { Indicator }\end{array}$ & $\begin{array}{c}\text { Score } \\
\text { Terbobot }\end{array}$ & Usulan Perbaikan (Respon Teknis) \\
\hline \multirow[t]{3}{*}{ Customer } & $\begin{array}{l}\text { - Prosentase jumlah } \\
\text { karyawan yang } \\
\text { melanggar kontrak } \\
\text { kerja }\end{array}$ & 0.171 & $\begin{array}{l}\text { Yang dimaksud karyawan yang melanggar kontrak kerja } \\
\text { adalah karyawan yang keluar dari perusahaan karena } \\
\text { melanggar perjanjian kerja yang telah disepakati } \\
\text { bersama. Untuk mengurangi hal tersebut, maka } \\
\text { perusahaan perlu menciptakan lingkungan kerja yang } \\
\text { mendukung karyawan dalam bekerja, memperbanyak } \\
\text { fasilitas - fasilitas dari perusahaan kepada karyawan, } \\
\text { misalnya pemberian gaji yang sesuai dengan kinerja } \\
\text { karyawan, memperbanyak tunjangan - tunjangan. dan } \\
\text { sebagainya. Peningkatan KPI ini berhubungan dengan } \\
\text { peningkatan kepuasan karyawan. }\end{array}$ \\
\hline & $\begin{array}{l}\text { - Tingkat kepuasan } \\
\text { karyawan / Employee } \\
\text { Satisfaction Index } \\
\text { (ESI) }\end{array}$ & 1.029 & $\begin{array}{l}\text { Indikator ini perlu diperhatikan oleh setiap perusahaan } \\
\text { untuk mengurangi jumlah karyawan keluar, menekan } \\
\text { jumlah karyawan absen dan karyawan yang mendapat } \\
\text { surat peringatan. Sehingga karyawan akan lebih betah } \\
\text { bekerja pada perusahaan dan akan menghasilkan } \\
\text { pekerjaan yang berkualitas tinggi. Peningkatan } \\
\text { pemenuhan kebutuhan karyawan sesuai dengan } \\
\text { kemampuan perusahaan dapat dilakukan dengan } \\
\text { peningkatan elemen - elemen yang mempengaruhi } \\
\text { tingkat kepuasan karyawan. Elemen - elemen tersebut } \\
\text { terdapat pada item - item pertanyaan kuisioner kepuasan } \\
\text { karyawan yang terdapat pada lampiran II. }\end{array}$ \\
\hline & $\begin{array}{l}\text { Waktu rata - rata } \\
\text { karyawan menganggur } \\
\text { karena rolling }\end{array}$ & 0.528 & $\begin{array}{l}\text { Waktu rata - rata satpam menganggur dapat } \\
\text { diminimalisasi jika perusahaan dapat menciptakan suatu } \\
\text { sistem penjadwalan alternatif jika ada peningkatan } \\
\text { permintaan dengan menempatkan sementara personel } \\
\text { yang ada di site. Dan tidak melakukan rekruitmen } \\
\text { apabila tidak ada peningkatan permintaan. Selain itu } \\
\text { pihak managemen juga harus cepat mengambil tindakan } \\
\text { dengan cara segera memperpanjang kontrak dengan klien } \\
\text { apabila masa kontrak sudah hampir habis. }\end{array}$ \\
\hline \multirow[t]{3}{*}{$\begin{array}{l}\text { Internal } \\
\text { Business } \\
\text { Process }\end{array}$} & $\begin{array}{l}\text { - Prosentase } \\
\text { tertangkapnya kasus } \\
\text { pencurian }\end{array}$ & 0.456 & $\begin{array}{l}\text { Pada KPI ini hasil yang didapat sudah mencapai target } \\
\text { perusahaan, sehingga tidak diperlukan perbaikan. Tetapi } \\
\text { untuk menghasilkan kinerja yang baik sesuai dengan } \\
\text { tujuan perusahaan, maka KPI ini harus dipertahankan } \\
\text { atau lebih ditingkatkan lagi. }\end{array}$ \\
\hline & $\begin{array}{l}\text { - Prosentase peningkatan } \\
\text { permintaan personel }\end{array}$ & 1.443 & $\begin{array}{l}\text { Pada KPI ini hasil yang didapat sudah mencapai target } \\
\text { perusahaan, sehingga tidak diperlukan perbaikan. Tetapi } \\
\text { untuk menghasilkan kinerja yang baik sesuai dengan } \\
\text { tujuan perusahaan, maka KPI ini harus dipertahankan } \\
\text { atau lebih ditingkatkan lagi. }\end{array}$ \\
\hline & $\begin{array}{l}\text { - Prosentase frekuensi } \\
\text { internal meeting }\end{array}$ & 1.62 & $\begin{array}{l}\text { Pada KPI ini hasil yang didapat sudah mencapai target } \\
\text { perusahaan, sehingga tidak diperlukan perbaikan. Tetapi } \\
\text { untuk menghasilkan kinerja yang baik sesuai dengan } \\
\text { tujuan perusahaan, maka KPI ini harus dipertahankan } \\
\text { atau lebih ditingkatkan lagi. }\end{array}$ \\
\hline $\begin{array}{l}\text { Learning } \\
\text { \& Growth }\end{array}$ & $\begin{array}{l}\text { - Prosentase karyawan } \\
\text { yang lulus Basic } \\
\text { Training }\end{array}$ & 3 & $\begin{array}{l}\text { Pada KPI ini hasil yang didapat sudah mencapai target } \\
\text { perusahaan, sehingga tidak diperlukan perbaikan. Tetapi } \\
\text { untuk menghasilkan kinerja yang baik sesuai dengan } \\
\text { tujuan perusahaan, maka KPI ini harus dipertahankan } \\
\text { atau lebih ditingkatkan lagi. }\end{array}$ \\
\hline
\end{tabular}




\begin{tabular}{|l|l|l|l|}
\hline $\begin{array}{l}\text { Regular Training } \\
\text { Prosentase jumlah }\end{array}$ & 0.8 & $\begin{array}{l}\text { Pada KPI ini hasil yang didapat sudah mencapai target } \\
\text { perusahaan, sehingga tidak diperlukan perbaikan. Tetapi } \\
\text { untuk menghasilkan kinerja yang baik sesuai dengan } \\
\text { tujuan perusahaan, maka KPI ini harus dipertahankan } \\
\text { atau lebih ditingkatkan lagi. }\end{array}$ \\
\hline $\begin{array}{l}\text { - Jumlah jam pelatihan } \\
\text { yang diadakan oleh } \\
\text { perusahaan bagi } \\
\text { karyawannya }\end{array}$ & 0.6 & $\begin{array}{l}\text { Jumlah jam pelatihan dapat ditingkatkan agar mencapai } \\
\text { target perusahaan dengan cara menindak tegas peserta } \\
\text { yang tidak mengikuti pelatihan. Memberi sanksi atau } \\
\text { hukuman sesuai pelanggaran yang dilakukan tiap } \\
\text { personel. Karena dengan meningkatnya ketrampilan } \\
\text { maka perusahaan akan maju dengan pesat dan semakin } \\
\text { banyak jam pelatihan dan jumlah peserta, maka akan } \\
\text { meningkatkan kualitas dari karyawan. Terciptanya } \\
\text { security yang profesional di lingkungan perusahaan } \\
\text { dalam bidang keamanan, keselamatan dan ketertiban. }\end{array}$ \\
\hline
\end{tabular}

\section{KESIMPULAN DAN SARAN \\ Kesimpulan}

Beberapa kesimpulan yang dapat ditarik dari hasil penelitian ini adalah sebagai berikut :

1. Pengukuran kinerja karyawan perusahaan PT. Shelter Nusantara secara keseluruhan adalah sedang untuk tahun 2007. Nilai ini dapat dilihat dari skor yang dihasilkan pada pengukuran kinerja sumber daya manusia dengan menggunakan metode Human Resources Scorecard, yaitu berada pada level 3.342. Sedangkan skor untuk tiap perspektif adalah sebagai berikut :

- Untuk Perspective Financial sebesar 3.252.

- Untuk Perspective Customer sebesar 2.686.

- Untuk Perspective Internal Business Process sebesar 3.519.

- Untuk Perspective Learning and Growth sebesar 4.4.

2. Usulan perbaikan yang diberikan untuk KPI yang belum memenuhi target perusahaan, antara lain :

a. Perspective Customer, Usulan perbaikan yang diberikan pada KPI Prosentase karyawan yang mendapat SP adalah dengan memberikan sanksi tegas dan konsekuensi sesuai dengan jenis pelanggaran dan berapa kali pelanggaran yang dilakukan oleh karyawan. KPI Prosentase karyawan yang melanggar kontrak kerja adalah dengan menciptakan lingkungan kerja yang mendukung, memperbanyak fasilitas - fasilitas dari perusahaan kepada karyawan. KPI prosentase Employee Satisfaction Index adalah dengan peningkatan pemenuhan kebutuhan karyawan sesuai dengan kemampuan perusahaan. Sedangkan KPI Waktu rata - rata karyawan menganggur karena rolling adalah dengan tidak melakukan rekruitmen apabila tidak ada peningkatan permintaan, selain itu pihak managemen juga harus cepat mengambil tindakan dengan cara segera memperpanjang kontrak dengan klien apabila masa kontrak sudah hampir habis.

b. Perspective Learning and Growth, Usulan perbaikan yang diberikan pada KPI jumlah jam pelatihan adalah dengan memberi sanksi atau hukuman tegas agar peserta mengikuti sesuai jadwal. 


\section{Saran}

1. Untuk mengevaluasi kinerjanya, sangat penting bagi pihak PT. Shelter Nusantara untuk melakukan pengukuran kinerja karyawan secara berkelanjutan menggunakan sistem pengukuran kinerja yang telah dirancang. Dari sinilah perusahaan dapat mengetahui dengan pasti kondisi perusahaan secara detail dan berkelanjutan, serta apa saja yang masih memerlukan perhatian perusahaan untuk diperbaiki.

2. Untuk pengukuran kinerja sumber daya manusia di masa yang akan datang, tidak tertutup kemungkinan untuk melakukan perubahan kriteria peningkatan kinerja sumber daya lain, sesuai dengan kondisi perusahaan.

\section{DAFTAR PUSTAKA}

Arikunto, Suharsimi. 1998. "Prosedur Penelitian Suatu Pendekatan Praktek", Rineka Cipta, Jakarta.

Becker Brian E, Hunselid Mark A, Ulrich Dave. 2001. "The HR Scorecard : Lingking People, Strategy, and Performance", Harvard Business School Press.

Brodjonegoro, Bambang P.S, 1992, "Analythical Hierarchy Process", PAU-EKUI, Jakarta.

Furtwengler, dale. 2000. "Penilaian Kinerja". Andi, Yogyakarta.

http://www.lmfeui.com/uploads/file111-XXX-November-2001.PDF.Human

Resources Scorecard : Suatu Model Pengukuran Kinerja SDM.

Kaplan, R.S dan Norton, D.P. 2000, “ Balance Scorecard : Menerapkan Strategi Menjadi Aksi “, Erlangga, Jakarta.

Mangkunegara, Dr. A. A. Anwar, Drs, M.Si. 2005. "Evaluasi Kinerja SDM", Cetakan Pertama, PT. Refika Aditama, Bandung.

Mangkunegara, Dr. A. A. Anwar, Drs, M.Si.P.Si. 2005. "Manajemen Sumber Daya Manusia Perusahaan", Cetakan keempat, PT. Remaja Rosdakarya, Bandung.

Pfeffer J, Soetjipto B.W, Handoko T.H, Djamaludin A, Dharma S, Peniwati K, Pradiansyah A, Adi PS W, dll. 2002, "Paradigma Baru Manajemen Sumber Daya Manusia “, Amara Books, Jakarta.

Saaty, Thomas L. 1993, "Pengambilan Keputusan Bagi Para Pemimpin”, PT. Pustaka Binaman Presisndo, Jakarta.

Sudjana. 1996. "Metode Statistika", Tarsito, Bandung. 